\author{
Ante Zdilar, mag. oec. \\ Asistent \\ Sveučilište u Dubrovniku \\ Odjel za ekonomiju i poslovnu ekonomiju \\ E-mail: azdilar@unidu.hr \\ Orcid: https://orcid.org/0000-0001-9411-3409
}

\title{
KRETANJA NA TRŽIŠTU RADA U HRVATSKOJ I EUROPSKOJ UNIJI: VAŽNOST FORMALNIH INSTITUCIJA
}

\author{
UDK / UDC: 331.5(497.5-4-67 EU) \\ JEL klasifikacija / JEL classification: J20, J21 \\ DOI: $10.17818 / \mathrm{EMIP} / 2021 / 1.4$ \\ Prethodno priopćenje / Preliminary communication \\ Primljeno / Received: 30. siječnja 2021. / January 30, 2021 \\ Prihvaćeno za tisak / Accepted for publishing: 25. svibnja 2021. / May 25, 2021
}

\section{Sažetak}

Zaostajanje Republike Hrvatske za vodećim zemljama članicama Europske unije uvijek je bila jedna od dominantnih tema empirijskih istraživanja u domaćoj ekonomskoj znanosti. Situacija na tržištu rada u 2019. godini, gdje Republika Hrvatska bilježi jedne od najnižih stopa zaposlenosti i stopa participacije, samo dodatno potvrđuje činjenicu relativnog zaostajanja u odnosu prema vodećim zemljama članicama Europske unije. Cilj ovog istraživanja je istražiti vezu između institucionalnog okvira, kao jednog od mogucih faktora zaostajanja, ukupne stope zaposlenosti $i$ stope zaposlenosti mladih u 27 zemalja članica Europske unije u razdoblju od 2002. do 2018. godine. Rezultati istraživanja ukazuju da je ta veza pozitivna i statistički signifikantna, kako za ukupnu stopu zaposlenosti, tako i za stopu zaposlenosti mladih.

Ključne riječi: stopa zaposlenosti, stopa zaposlenosti mladih, institucije, Republika Hrvatska, panel, Europska unija.

\section{UVOD}

Jedan od glavnih ciljeva zemalja širom svijeta u nadolazećem postpandemijskom svijetu bit će zadržavanje zaposlenosti, odnosno sprečavanje rasta nezaposlenosti unutar okvira u kojima je to moguće. Navedeni izazov neće mimoići niti najjače ekonomije svijeta zbog činjenice da je kriza COVID - 19 jedan od presedana u cijeloj ljudskoj i ekonomskoj povijesti. Zadržavanje stope zaposlenosti na istoj razini prije COVID - 19 krize biti će izazov koji će uvelike 
ovisiti o fiskalnim kapacitetima, ali i institucionalnom okviru unutar kojeg pojedine zemlje temelje svoje ekonomske aktivnosti. Douglass North (1990), dobitnik Nobelove nagrade 1993. godine zbog doprinosa u području institucionalne ekonomije, institucije definira kao „pravila igre“ $u$ društvu, ili formalnije, institucije su ljudski osmišljena ograničenja koja oblikuju ljudsku interakciju. Međutim, prilikom analiziranja različitih institucionalnih okvira potrebno je pravili razliku između formalnih i neformalnih institucija. Formalne institucije spadaju u sferu legalnih aktivnosti koje su pod ingerencijom vlade pojedine zemlje te se mogu jako brzo preoblikovati kako bi se prilagodile novonastalim okolnostima. S druge strane, neformalne institucije se odnose na različite oblike ilegalnih aktivnosti pravnih i fizičkih osoba. U empirijskom dijelu rada od različitih dostupnih baza (Europska banka za obnovu i razvoj, Heritage Foundation, Freedom House i sl.), koje mjere učinke formalnih institucija, koristit će se baza Svjetske banke.

Stopa zaposlenosti predstavlja udio radno sposobnog stanovništva $\mathrm{s}$ plaćenim poslom te zanemaruje razlike između zaposlenika u vidu radnog vremena i duljine trajanja ugovora (Brandolini \& Viviano, 2018, str. 3). Prema definiciji Međunarodne organizacije rada postoje razlike između mjerenja stopa nezaposlenosti i stope zaposlenosti. Naime, za razliku od stope nezaposlenosti koja se mjeri u odnosu na aktivno stanovništvo, odnosno radnu snagu, stopa zaposlenosti se mjeri u odnosu na radno sposobno stanovništvo (International Labour Organization, 2017, str. 21). Jednako tako, stopa zaposlenosti je puno relevantniji pokazatelj trenutačnog stanja na tržištu rada u odnosu prema stopi nezaposlenosti koja može biti pod utjecajem određenih čimbenika koji nisu uzeti u obzir. Najbolji primjer predstavlja upravo Republika Hrvatska u kojoj je došlo do pada stope nezaposlenosti nakon ulaska u Europsku uniju, ali postavlja se pitanje koliko je to rezultat poboljšanja, kako na tržištu rada, tako i u cijeloj ekonomiji, a koliko rezultat masovnog iseljavanja u razvijene zemlje Europske unije.

Razlike u stopama zaposlenosti između različitih zemalja u svijetu rezultat su niza različitih faktora poput produktivnosti rada, tehnološkog napretka, investicija, izravnih inozemnih ulaganja i sl. Međutim, jedan od faktora kojeg je posebno potrebno uzeti $u$ obzir prilikom analiziranja zaposlenosti između različitih zemalja je institucionalni okvir unutar kojeg pojedina zemlja djeluju. Drugim riječima, potrebno je uzeti u obzir formalne institucije, odnosno ,pravila igre" unutar kojih se obavljaju ekonomske interakcije između različitih ekonomskih subjekata. Postojeća istraživanja (Vujčić 1998; Botić i Tomić, 2016; Bečić i Vojinić, 2019) razmatraju različite učinke (rast plaća, restrukturiranje, motiva samozapošljavanja i sl.) na kretanja zaposlenosti/nezaposlenosti na tržištu rada, te je uočen jaz u vidi utjecaja institucija na navedene parametre. U ovom radu cilj je istražiti kako institucionalni okvir unutar 27 zemalja članica Europske unije djeluje na stopu zaposlenosti i stopu zaposlenosti mladih u periodu 2002 2018 godine. U radu je korištena standardizirana pooled OLS metoda i panel metoda s random efektima. 
Rad je strukturiran na sljedeći način. U drugom poglavlju predstavljen je pregled literature vezan za zaposlenost i institucionalni okvir. Treće poglavlje analizira deskriptivnu statistiku u vidu povijesnih kretanja stopa zaposlenosti i stopa participacije u Republici Hrvatskoj i odabranim zemljama članicama Europske unije. U četvrtom poglavlju opisana je metodologija mjerenja učinka institucija. dok se peto poglavlje odnosi na opis podataka i metodologije istraživanja. U šestom poglavlju su predstavljeni rezultati istraživanja, dok je sedmo poglavlje zaključak rada.

\section{PREGLED LITERATURE}

U empirijskim istraživanjima institucionalni okvir uglavnom je vezan za BDP per capita ili stopu rasta BDP-a. Tako Efendić i Pugh (2010) koristeći se GMM metodom pokazuju da poboljšanje institucija pozitivno djeluje na BDP per capita. Dobiveni rezultati sugeriraju da poboljšanje institucija u tranzicijskom razdoblju tijekom pet godina za deset posto, prema standardima razvijenih tržišnih ekonomija, rezultira povećanjem BDP per capita za $4 \%$ u prosjeku, uz ostale varijable jednake (Efendić i Pugh, 2010, str. 17). Autori su za mjerenje institucija koristili bazu EBRD-a.

Nadalje, Sachs (1996) također koristi bazu EBRD-a te pokazuje da indeks reformskog progresa, koji je dobiven na temelju sumiranja 9. indikatora Europske banke za obnovu i razvoju, pozitivno djeluje na prosječni godišnji rast BDP-a. Analiza je provedena na temelju 25 zemalja u razdoblju od 1989. do 1995. godine. Za razliku od njih, Paakkonen (2009) kao mjeru institucija koristi indeks ekonomskih sloboda te koristeći se GMM-om zaključuje da su zdrave institucije jako bitna komponenta u ekonomskom okruženju, koja pozitivno utječe na ekonomske slobode koje su nužne za postizanje visokih stopa rasta.

Tomić i drugi (2019) također ističu važnost razlikovanja stope zaposlenosti i stope nezaposlenosti. Unatoč padu ukupne nezaposlenosti, Hrvatska i dalje ima jednu od najvećih stopa nezaposlenosti u Europskoj uniji u kategoriji starije populacije i u kategoriji mlade populacije, dok su stopa participacije i stopa zaposlenosti jedne od najnižih u Europskoj uniji (Tomić i ostali, 2019, str. 8). Naime, u 2018. godini ukupna stopa zaposlenosti za populaciju stariju od 15 godina iznosila je samo 46,9 \%, dok ista stopa za populaciju od 20 do 64 godine iznosila $65,2 \%$, što Hrvatsku svrstava u kategoriju zemalja s najnižim stopama (lošije stope imaju samo Grčka i Italija). Nadalje, stopa samozapošljavanja u Republici Hrvatskoj u 2018. godini iznosila je 10,8 \%, dok je prosjek Europske unije u 2018. godini 14,3\%. Bejaković i Gotovac (2011) ističu važnost ugovora o radu na određeno vrijeme i ugovora o radu na neodređeno vrijeme. Autori ističu kontinuirani par udjela osoba u ukupnoj zaposlenosti koje su radile na temelju ugovora na određeno vrijeme u razdoblju 2008. - 2010. godine. Navedena činjenica jednim dijelom je i logična s obzirom na globalnu ekonomsku krizu koja je nastupila i s obzirom na činjenicu da poslodavci nakon isteka ugovora o radu na određeno vrijeme radniku mogu 
uručiti otkaz bez eventualnih dodatnih troškova. S druge strane, udio osoba koje su radile na temelju ugovora o radu s nepunim radnim vremenom u promatranom razdoblju uglavnom je ostao stabilan.

Bečić i Vojinić (2019) ističu važnost nestandardnih oblika zapošljavanja u Republici Hrvatskoj u vidu privremenih i neizvjesnih zapošljavanja čiji je broj rapidno porastao od 2014. godine u svim sektorima industrije. Autorice su pronašle statistički signifikantnu pozitivnu vezu između privremenih i neizvjesnih oblika zapošljavanja i rasta plaća. Drugim riječima, poslodavci ako žele pronaći radnike koji će raditi na kraće razdoblje moraju biti spremni ponuditi i veće plaće za to razdoblje. Autorice također zaključuju da ne postoji statistički signifikantna veza između rada $\mathrm{s}$ nepunim radnim vremenom i rasta plaća. Taj se rezultat jednim dijelom može objasniti malim udjelom ljudi koji rade na nepunom radnom vremenu (4 sata) u ukupnoj zaposlenosti te niskim plaćama u slučaju prihvaćanja takvog oblika rada.

Vujčić (1998) ističe zaostajanje strukture zaposlenosti Republike Hrvatske u odnosu na ostale zemlje članice Europske unije. Nadalje, autor ističe da je restrukturiranje zaposlenosti u Republici Hrvatskoj bilo najuspješnije u prvih sedam godina tranzicije te da najteža faza, faza kreiranja zaposlenja radi sustizanja ostalih zemalja članica Europske unije, tek slijedi. Nažalost, prema dostupnim podatcima strukture zaposlenosti i dalje postoji izraženo zaostajanje Republike Hrvatske u odnosu prema najrazvijenijim zemljama članicama Europske unije.

Botić i Tomić (2016) analiziraju razlike između samozapošljavanja u mladoj i starijoj populaciji u Republici Hrvatskoj. Veliki udio starije populacije okrenuo se samozapošljavanju zbog nužnosti, dok se veliki udio mlađe populacije okrenuo samozapošljavanju zbog mogućnosti (Botić i Tomić, 2016, str. 23). Autorice također ističu pad samozapošljavanja kod mladih u Republici Hrvatskoj s 3,5\% u 2007. godini na 2,5\% u 2013. godini te pad samozapošljavanja kod starije populacije s $12,4 \%$ u 2007 . godini na $10,0 \%$ u 2013. godini. Nadalje, udio samozaposlenih osoba u ukupnoj zaposlenosti kod mladih osoba u Republici Hrvatskoj je bio isti 2007. i 2008. godine te je iznosio $8 \%$, dok je kod starijih osoba došlo do pada s $26 \%$ u 2007. godini na $22 \%$ u 2013. godini.

Institucije predstavljaju komponentu koja kroz različite mehanizme uvelike utječe na stopu gospodarskog rasta u zemljama širom svijeta. Ti mehanizmi uključuju različite aspekte gospodarskog uređenja od zakonodavnog, društvenog, tržišnog i sl. Republika Hrvatska još od svoje samostalnosti bilježi određen stupanj zaostajanja (jednim djelom zbog rata) u različitim aspektima društva, što se posljedično reflektira i kroz tržište rada. To zaostajanje nastavilo se i nakon ulaska Hrvatske u Europsku uniju te se nije uvelike mijenjalo $\mathrm{s}$ pojavom nestandardiziranih oblika zapošljavanja. 


\section{POVIJESNI PRESJEK KRETANJA STOPA ZAPOSLENOSTI I STOPE PARITCIPACIJE U HRVATSKOJ I EUROPSKOJ UNIJI}

Prije samog prelaska na empirijski dio rada, na temelju podataka Eurostata analizirat će se situacija na tržištu rada u Republici Hrvatskoj u usporedbi s odabranim zemljama članicama Europske unije.

$\mathrm{Na}$ temelju podataka iz slike 1. može se zaključiti da je zaostajanje Republike Hrvatske, koje je Vujčić (1998) prepoznao u tranzicijskom razdoblju, također nastavljeno i u razdoblju od 2005. do2019. godine. Konkretno, stopa zaposlenosti Republike Hrvatske kontinuirano je niža od 2009. godine i u usporedbi s odabranim zemljama članicama EU-a i u usporedbi s prosjekom EU27 zemalja. Činjenica koja dodatno zabrinjava je konstantnost ,jaza“ od 2013. godine, što samo potvrđuje dodatno zaostajanje Republike Hrvatske u odnosu prema odabranim zemljama članicama Europske unije. Jedine dvije zemlje u promatranoj analizi koje imaju stopu zaposlenosti iznad prosjeka EU27 zemalja su Češka i Slovenija.

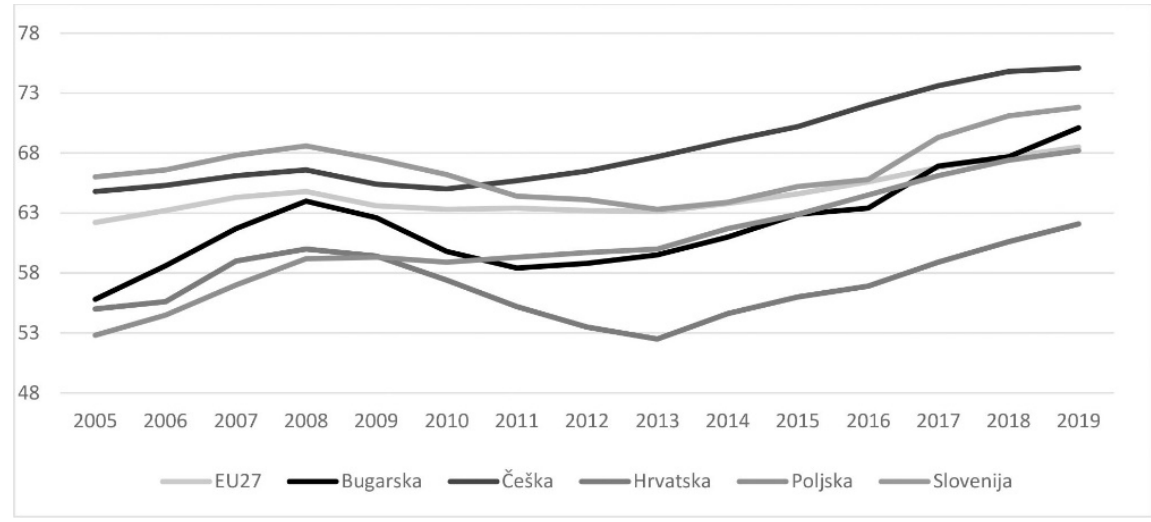

Slika 1. Kretanje stope zaposlenosti (15 - 64) u Republici Hrvatskoj, Bugarskoj, Sloveniji, Češkoj i Poljskoj u razdoblju od 2005. do 2019. godine

Izvor: Eurostat

Ako se analiziraju trendovi kretanja stope zaposlenosti mladih (slika 2.), situacija je nešto povoljnija za Republiku Hrvatsku koja je u 2019. godini imala stopu zaposlenosti mladih $(27,7$ \%) približno jednaku Češkoj (28 \%). Prosjek EU27 zemalja za 2019. godinu iznosio je 33,5 \%, što je 5,8 postotnih poena više u odnosu prema Republici Hrvatskoj. Usporedbe radi, i kod stope zaposlenosti mladih u 2019. godini, opet je Slovenija zemlja koja ima stopu zaposlenosti mladih $(33,3 \%)$ približno jednaku prosjeku EU27 zemalja. U 2020. godini i jednim dijelom 2021. godini može se očekivati pogoršanje trendova zaposlenosti u svim zemljama članicama Europske unije zbog krize prouzrokovane virusom COVID - 19. Kolike će biti posljedice krize 
ovisi o svakoj zemlji pojedinačno, odnosno njezinim fiskalnim kapacitetima i mogućnostima prilagođavanja s obzirom na nastalu situaciju.

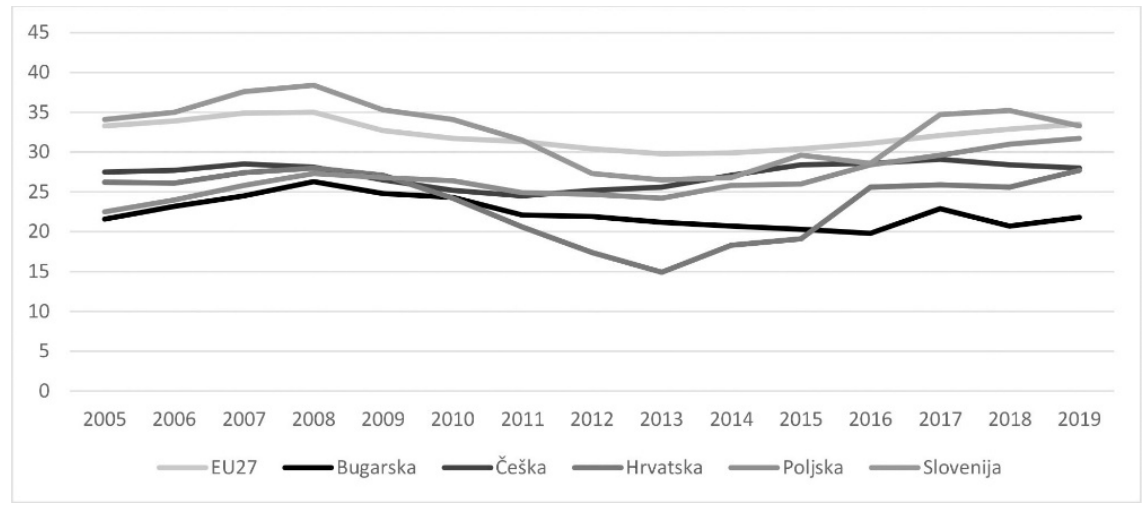

Slika 2. Kretanje stope zaposlenosti mladih (15 - 24) u Republici Hrvatskoj, Bugarskoj, Sloveniji, Češkoj i Poljskoj u periodu od 2005. do 2019. godine Izvor: Eurostat

Nadalje, na slici 3. može se vidjeti da Republika Hrvatska ni u 2019. godini nije dostigla razinu ukupne stope zaposlenosti i stope zaposlenosti mladih koje je Slovenija imala 2005. godine. U odnosu na Sloveniju, ukupna stopa zaposlenosti u 2019. godini je u Republici Hrvatskoj 8,7 postotnih poena niža dok je stopa zaposlenosti mladih 6,1 postotni poen niža. Ako se analizira Republika Hrvatska u odnosu prema prosjeku EU27 zemalja, ukupna stopa zaposlenosti je niža 3,7 postotnih poena, dok je stopa zaposlenosti mladih niža 5,8 postotnih poena u Republici Hrvatskoj u 2019. godini.
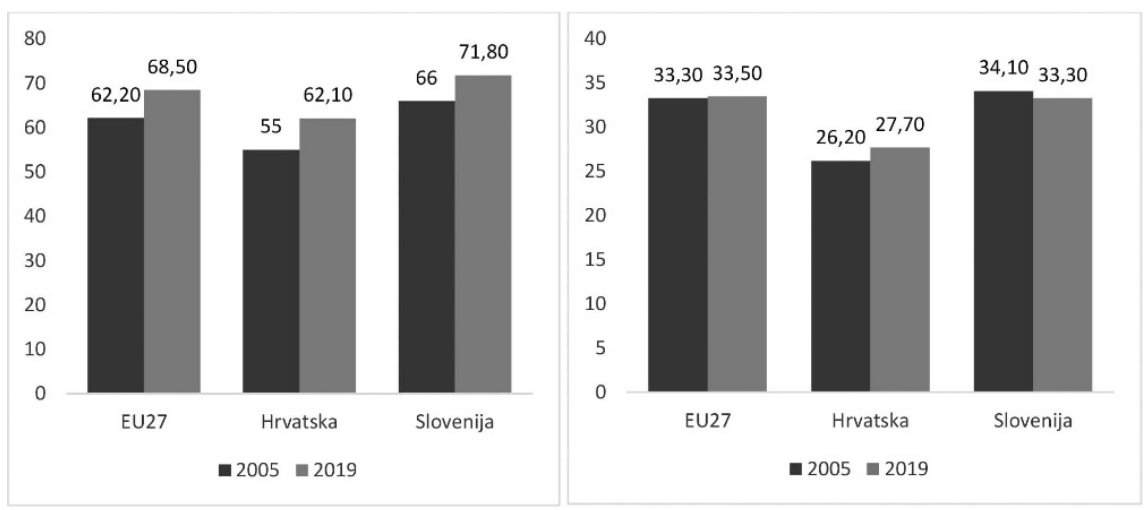

Slika 3. Usporedba stope zaposlenosti i stope zaposlenosti mladih u Hrvatskoj i Sloveniji u 2005. i 2019. godini

Izvor: Eurostat 
Jedan od značajnih indikatora aktivnosti na tržištu rada (uz stopu zaposlenosti) je i stopa participacije koja se izračunava po formuli:

$$
\text { stopa participacije }=\frac{\text { radna snaga }}{\text { radno sposobno stanovništvo }}
$$

Osnovni cilj stope participacije je, naravno, da prikaže koliki dio radno sposobnog stanovništva je aktivan na tržištu rada (aktivan znači ima ili aktivno traži posao) (Tica, 2015, str. 83). Drugim riječima, stopa participacije prikazuje sposobno stanovništvo koje nije obeshrabreno u smislu da ima ili da aktivno traži posao.

Na slici 4. može se vidjeti da Republika Hrvatska ima jednu od najlošijih stopa participacije u odnosu na ostale zemlje članice Europske unije. Konkretno, u 2019. godini iznosila je $66,5 \%$, što je 4,1 postotni poen manje u odnosu na Poljsku, 6,7 postotnih poena manje u odnosu na Bugarsku, 8,7 postotnih poena u odnosu na Sloveniju, 10,2 postotnih poena manje u odnosu na Češku te čak 16,4 postotna poena manje u odnosu na najbolje rangiranu zemlju Švedsku.

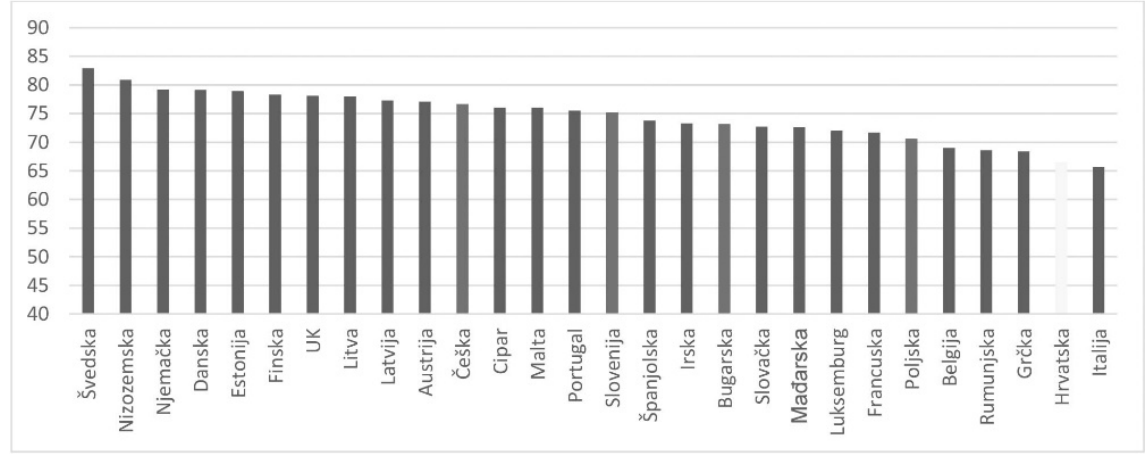

Slika 4. Stopa participacije - \% radno sposobnog stanovništva od 15 do 64 godine u zemljama članicama Europske unije u 2019. godini

Izvor: Eurostat

Jedina lošije rangirana zemlja u odnosu na Republiku Hrvatsku je Italija sa stopom participacije od 65,7 \% u 2019. godini. Razloge preniske stope participacije u Republici Hrvatskoj nije moguće jednoznačno odrediti budući da je ona rezultat nekoliko mjerljivih i nemjerljivih faktora. Jedan od razloga niske stope participacije je svakako visok udjel turizma u BDP-u, gdje zapravo određena nekolicina ljudi nije aktivno uključena u tržište rada, budući da uživa blagodati renterijerskog načina života. Nadalje, visok udjel turizma u BDP-u je također prouzročio određene anomalije na tržištu rada u vidu različitih (većih) nadnica u branšama niskokvalificirane radne snage u odnosu na (niže) nadnice visokokvalificirane radne snage. To posljedično može izazvati određenu demotivaciju mladih ljudi u smislu ulaganja u vlastito obrazovanje i karijeru. Jednako tako, jedna od nemjerljivih kategorija koju je potrebno uzeti u obzir je i 
mentalitet cijelog društva koji je nastao kao posljedica dugogodišnjeg upravljanja pod socijalizmom. Samim time jedan dio pojedinaca može stvoriti pogrešnu percepciju prema radu i cjelokupnoj ulozi države u gospodarstvu. Slično kao i kod stope zaposlenosti na slici 3., na slici 5. može se vidjeti da Republika Hrvatska ni u 2019. godini nije dostigla stopu participacije koju su Češka i Slovenija imale 2005. godine. Usporedbe radi, Republika Hrvatska je imala i najmanji porast stope participacije koji je u razdoblju 2005. - 2019. iznosio 3,2 postotna poena, dok je u Bugarskoj iznosio 11,1 postotnih poena, u Češkoj 6,3 postotnih poena, u Poljskoj 6,2 postotnih poena i u Sloveniji 4,5 postotnih poena.

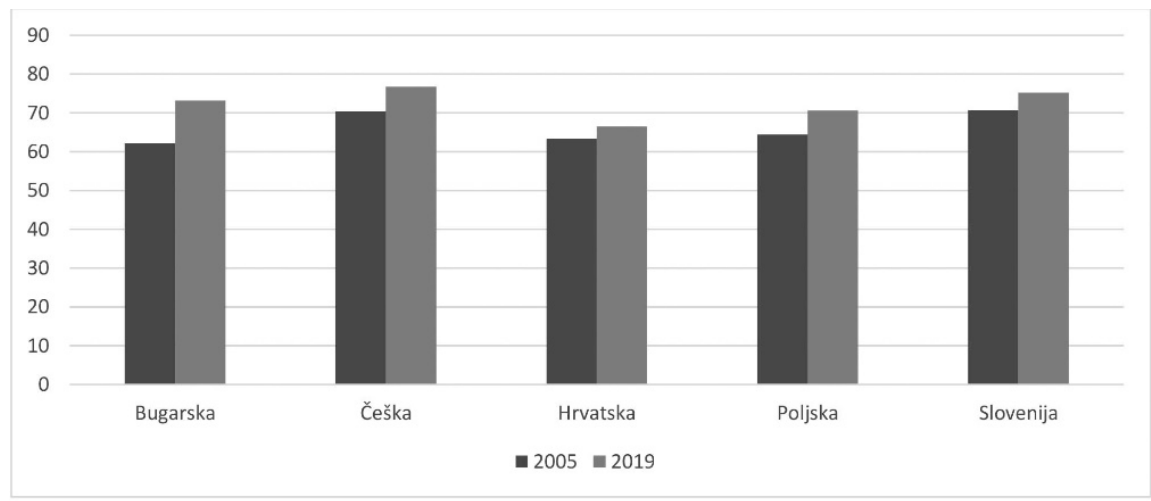

Slika 5. Stopa participacije - \% radno sposobnog stanovništva od 15 do 64 godine u odabranim zemljama članicama Europske unije u 2005. i 2019. godini.

Izvor: Eurostat

Ako se razmatra stopa participacije po spolu, situacija je sljedeća. $\mathrm{Na}$ slici 6. može se vidjeti kontinuirani trend veće stope participacije kod osoba muškog spola u Republici Hrvatskoj u odnosu na osobe ženskog spola u cijelom promatranom razdoblju. Navedeni rezultati svakako su jednim dijelom posljedica tradicionalnog obiteljskog načina života gdje je stopa participacije žena nešto niža u odnosu na stopu participacije muškaraca. Za očekivati je da će se u budućnosti ti trendovi mijenjati te da će se stope participacije po spolu kretati prema uravnoteženju. 


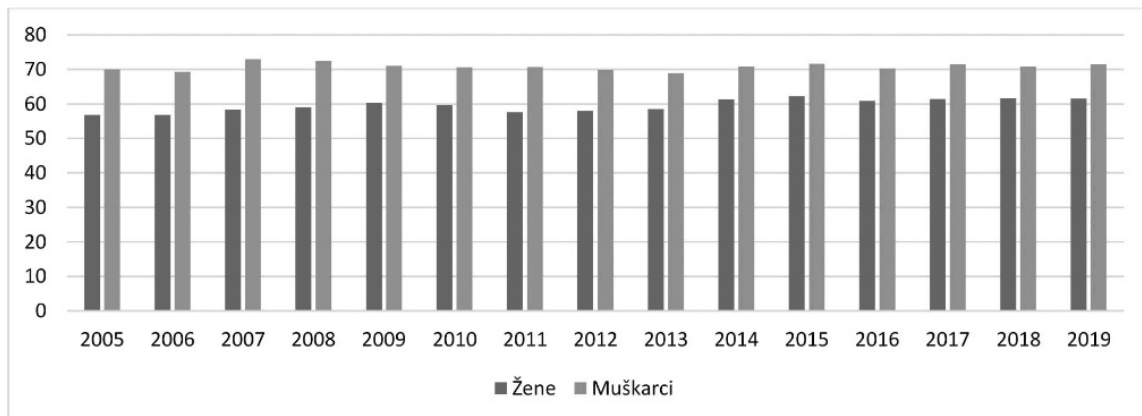

Slika 6. Stopa participacije - \% radno sposobnog stanovništva od 15 do 64 godine po spolu u Republici Hrvatskoj u razdoblju od 2005. do 2019. godine

Izvor: Eurostat

\section{MJERENJE UČINKA INSTITUCIJA}

Jedan od glavnih problema izučavanja institucionalne ekonomije je problem adekvatnog mjerenja učinka institucija na određenu ekonomsku aktivnost. U skladu s tim, različiti autori primjenjivali su različite metodologije i baze podataka u objašnjavanju učinka institucija na gospodarsku aktivnost. Pojedini autori koristili su bazu Europske banke za obnovu i razvoj (Sachs, 1996; Falcetti i drugi., 2006; Di Tommaso i drugi., 2007; Efendić i drugi., 2015), drugi su pak koristili indeks ekonomskih sloboda iz baze Heritage Foundation kao aproksimaciju učinka institucija (Radek i Susjan, 2005; Paakkonen, 2009), dok su treći koristili bazu Svjetske banke vezanu za Worldwide Governance indikatore (Lane i Rohner, 2004; Beck i Leaven, 2006; Aralica i drugi., 2018). U ovom radu koristit će se WGI baza svjetske banke koja uključuje šest osnovnih varijabli:

kontrolu korupcije (cc), efikasnost vlade (ge), političku stabilnost i odsustvo terorizma/nasilja (ps), kvalitetu regulacije (rq), vladavinu prava (rol) i pravo glasa i slobodu govora (va). Sve varijable koje su korištene u radu detaljno su opisane u dodatku (tablica 7.).

Tablica 1 .

Matrica korelacije između šest osnovnih institucionalnih pokazatelja

\begin{tabular}{|c|c|c|c|c|c|c|}
\hline Varijable & $(1)$ & $(2)$ & $(3)$ & $(4)$ & $(5)$ & $(6)$ \\
\hline $\mathrm{cc}$ & 1.000 & & & & & \\
\hline $\mathrm{ge}$ & 0.941 & 1.000 & & & & \\
\hline $\mathrm{ps}$ & 0.571 & 0.604 & 1.000 & & & \\
\hline $\mathrm{rq}$ & 0.891 & 0.874 & 0.593 & 1.000 & & \\
\hline $\mathrm{rol}$ & 0.948 & 0.939 & 0.618 & 0.908 & 1.000 & \\
\hline $\mathrm{va}$ & 0.919 & 0.904 & 0.609 & 0.884 & 0.931 & 1.000 \\
\hline
\end{tabular}

Izvor: izračun autora 
Međutim, zbog visoke koreliranosti između navedenih šest varijabli (tablica 1.) u radu će se koristiti PCA analiza (Principal components analysis) kako bi se smanjila višedimenzionalnost varijabli te kako bi se dobio jedan jedinstveni indeks koji će mjeriti učinak institucija na stopu zaposlenosti i stopu zaposlenosti mladih. Na taj način eliminirat će se i mogući problem multikoreliranosti varijabli u regresiji. Principal components analiza je statistička tehnika koja se primjenjuje na određeni skup varijabli kada je istraživač zainteresiran otkriti koje su varijable u zadanom skupu koherentne podskupine koje su relativno neovisne jedna o drugoj (Tabachnick \& Fidell, 2014, str. 660). Sama metoda sastoji se od kreiranja klastera varijabli eigenvektora koji su ortogonalni jedan nasuprot drugome. Iako eigenvektora ima koliko i klastera, najčešće je najveći broj varijacija objašnjen uz pomoć prvih nekoliko komponenti pri čemu se u obzir uzimaju samo one komponente čija je eigenvrijednost veća od 1 .

Tablica 2.

Principal components analiza

\begin{tabular}{|c|c|c|c|c|}
\hline Komponenta & Eigenvrijednost & Razlika & Proporcija & Kumulativno \\
\hline Comp1 & 5.094 & 4.530 & 0.849 & 0.849 \\
\hline Comp2 & 0.564 & 0.425 & 0.094 & 0.943 \\
\hline Comp3 & 0.139 & 0.041 & 0.023 & 0.966 \\
\hline Comp4 & 0.098 & 0.042 & 0.016 & 0.983 \\
\hline Comp5 & 0.056 & 0.008 & 0.009 & 0.992 \\
\hline Comp6 & 0.048 &. & 0.008 & 1.000 \\
\hline
\end{tabular}

Izvor: izračun autora

Kao što se može vidjeti u tablici 2., u ovom se slučaju u obzir uzima samo komponenta 1 . koja objašnjava 84,9 \% varijacija institucionalnih varijabli navedenih iznad.

Tablica 3.

Vrijednost i predznak varijabli u pojedinim komponentama

\begin{tabular}{|c|c|c|c|c|c|c|}
\hline Variable & Comp1 & Comp2 & Comp3 & Comp4 & Comp5 & Comp6 \\
\hline cc & 0.427 & -0.203 & -0.243 & 0.181 & 0.658 & 0.502 \\
\hline ge & 0.426 & -0.133 & -0.412 & 0.444 & -0.654 & 0.081 \\
\hline ps & 0.311 & 0.948 & -0.023 & 0.025 & 0.046 & 0.039 \\
\hline rq & 0.416 & -0.119 & 0.869 & 0.186 & -0.113 & 0.099 \\
\hline rol & 0.432 & -0.124 & -0.097 & 0.026 & 0.281 & -0.842 \\
\hline va & 0.424 & -0.114 & -0.080 & -0.857 & -0.215 & 0.145 \\
\hline
\end{tabular}

Izvor: izračun autora 
Budući da su u prvoj komponenti sve varijable pozitivne s približno jednakim vrijednostima (tablica 3.), to znači da prvu komponentu možemo interpretirati kao institucionalni okvir svake pojedine države unutar kojeg se obavljaju sve ekonomske aktivnosti. Samim time, zemlje koje imaju bolji institucionalni okvir trebale bi biti uspješnije u ostvarivanju viših stopa rasta, investicija, zaposlenosti i općenito višeg životnog standarda.

Adekvatnost uzorka za provođenje PCA analize testira se pomoću Kaiser-Meyer-Olkin testa čija ukupna vrijednost mora biti iznad 0,5 jer u suprotnom cijela PCA analiza nije adekvatna za određeni skup podataka. U navedenom slučaju ona iznosi 0,932 (tablica 4.).

Tablica 4.

Kraiser - Mayer - Olkin test adekvatnosti uzorka

\begin{tabular}{|c|c|}
\hline Varijable & KMO \\
\hline cc & 0.906 \\
\hline ge & 0.926 \\
\hline Ps & 0.963 \\
\hline rq & 0.962 \\
\hline rol & 0.904 \\
\hline va & 0.950 \\
\hline Ukupno & 0.932 \\
\hline
\end{tabular}

Izvor: izračun autora

\section{METODOLOGIJA RADA}

U empirijskom dijelu rada analizirat će se utjecaj institucionalnog okvira na stopu rasta zaposlenosti i stopu rasta zaposlenosti mladih u 27 zemalja Europske unije u razdoblju od 2002. do 2018. godine. U radu je korišten standardizirani pooled OLS model i panel model s random efektima. Osnovni sustav jednadžbi gdje $i$ predstavlja zemlju, a $t$ vrijeme je sljedeći:

$$
\begin{aligned}
& \text { 1) } Y_{i t}=\alpha_{1}+B_{1} g f c f_{i t}+B_{2} i n f_{i t}+B_{3} \operatorname{comp} 1_{i t}+B_{4} e u_{i t}+\varepsilon_{i t} \\
& \text { 2) } \hat{Y}_{i t}=\alpha_{1}+B_{1} g f c f_{i t}+B_{2} i n f_{i t}+B_{3} \operatorname{comp} 1_{i t}+B_{4} e u_{i t}+\varepsilon_{i t}
\end{aligned}
$$

gdje je $Y_{i t}$ stopa zaposlenosti, $\hat{Y}_{i t}$ stopa zaposlenosti mladih, gfcf su ostvarene investicije, inf inflacija, comp1 vrijednost institucionalnog indeksa (vrijednosti prikazane u dodatku - tablica 6.), eu dummy varijabla koja poprima vrijednost 1 ako je zemlja $i$ u godini $t$ bila zemlja članica Europske unije te $\varepsilon_{i t}$ slučajna greška (detaljan opis varijabli dostupan u dodatku - tablica 7.). Jednako tako, svaki od modela procijenjen je i s OLS metodom is panel metodom s random efektima te svaki od modela sadrži dummy varijable za godine zbog strukturnih lomova. 
Za očekivati je da postoji statistički signifikantna i pozitivna veza između institucionalnog okvira i stope zaposlenosti i stope zaposlenosti mladih. Pojedini autori pokazali su sličnu povezanost između institucionalnog okvira i realnog GDP per capita (Falcetti i drugi., 2002; Paakkonen, 2009; Efendic i drugi, 2015). Nadalje, jednako tako može se očekivati da je veza između stope zaposlenosti/stope zaposlenosti mladih i ostvarenih investicija također statistički signifikantna i pozitivna budući da veće investicije dovode do otvaranja novih radnih mjesta. Što se pak tiče inflacije i dummy varijable $e u$, tu se ne može sa sigurnošću tvrditi kakva veza se može očekivati budući da je veliki broj zemalja u promatranom razdoblju 2002. - 2018. već bilo članicama Europske unije (Cipar, Češka, Estonija, Latvija, Litva, Mađarska, Malta, Slovačka, Slovenija pristupile 2004. godine, Bugarska i Rumunjska 2007. godine i Hrvatska 2013. godine).

\section{REZULTATI ISTRAŽIVANJA}

U tablici 5. prikazani su rezultati panel analize koristeći se stopom zaposlenosti i stopom zaposlenosti mladih kao zavisne varijable. Prva dva modela napravljena su na temelju standardizirane pooled OLS metode. U prvom modelu, sa stopom zaposlenosti mladih, može se vidjeti da su četiri osnovne varijable statistički signifikantne s tim da su tri varijable pozitivnog predznaka, a dummy varijabla (eu) negativnog predznaka. Ostvarene investicije (gfcf) i institucionalni index (comp1) pozitivnog su predznaka i statistički signifikantne na razini od 1 $\%$, dok je inflacija (inf) također pozitivnog predznaka i statistički signifikantna, ali na razini od $5 \%$. Dummy varijabla (eu) jedina je varijabla koja je negativnog predznaka i koja je signifikantna tek na razini od $10 \%$.

Drugi model kao zavisnu varijablu koristi ukupnu stopu zaposlenosti te su rezultati približno slični prvom modelu. Ostvarene investicije (gfcf) i institucionalni indeks (comp1) ponovno su pozitivnog predznaka i statistički signifikantni na razini od $1 \%$ kao i u prvom modelu, dok je inflacija (inf) pozitivnog predznaka i statistički signifikantna na razini od $1 \%$. S druge strane, za razliku od prvog modela, u drugom modelu dummy varijabla (eu) nije statistički signifikantna. Međutim, treba imati na umu da pooled OLS metoda koja je korištena u prvom i drugom modelu ne razlikuje zemlje koje su korištene u modelu. Drugim riječima, ta metoda niječe heterogenost i individualnost koja postoji među navedenim zemljama članicama Europske unije. Slijedom navedenoga, rezultate treba uzeti s dozom rezerve. 
Rezultati panel analize

Tablica 5.

\begin{tabular}{|c|c|c|c|c|}
\hline & $(1)$ & $(2)$ & (3) & (4) \\
\hline & Pooled OLS & Pooled OLS & $\mathrm{RE}$ & $\mathrm{RE}$ \\
\hline & szm & $\mathrm{sZ}$ & szm & $\mathrm{sZ}$ \\
\hline \multirow[t]{2}{*}{ gfcf } & $0.444 * * *$ & $0.429 * * *$ & $0.453 * * *$ & $0.329 * * *$ \\
\hline & $(0.113)$ & $(0.046)$ & $(0.165)$ & $(0.086)$ \\
\hline \multirow[t]{2}{*}{ inf } & $0.418 * *$ & $0.277 * * *$ & 0.281 & 0.172 \\
\hline & $(0.196)$ & $(0.101)$ & $(0.199)$ & $(0.133)$ \\
\hline \multirow[t]{2}{*}{ comp1 } & $4.129 * * *$ & $1.603 * * *$ & $2.980 * * *$ & $1.460 * * *$ \\
\hline & $(0.229)$ & $(0.074)$ & $(1.004)$ & $(0.513)$ \\
\hline \multirow[t]{2}{*}{$\mathrm{eu}$} & $-2.761 *$ & 0.153 & 0.597 & 0.872 \\
\hline & $(1.485)$ & $(0.757)$ & $(1.172)$ & $(0.907)$ \\
\hline \multirow[t]{2}{*}{$\mathrm{yr} \_1$} & -3.434 & $-4.854 * * *$ & -0.991 & $-4.068 * * *$ \\
\hline & $(2.618)$ & $(1.158)$ & $(1.429)$ & $(0.869)$ \\
\hline \multirow[t]{2}{*}{$\mathrm{yr} \_2$} & -3.747 & $-4.538 * * *$ & -1.497 & $-3.823 * * *$ \\
\hline & $(2.619)$ & $(1.128)$ & $(1.381)$ & $(0.841)$ \\
\hline \multirow[t]{2}{*}{$\mathrm{yr} \_3$} & -3.320 & $-4.721 * * *$ & $-2.363^{*}$ & $-4.222 * * *$ \\
\hline & $(2.371)$ & $(1.095)$ & $(1.237)$ & $(0.782)$ \\
\hline \multirow[t]{2}{*}{ yr_4 } & -3.049 & $-4.384 * * *$ & $-2.199 *$ & $-3.872 * * *$ \\
\hline & $(2.243)$ & $(1.019)$ & $(1.143)$ & $(0.772)$ \\
\hline \multirow[t]{2}{*}{ yr_5 } & -2.692 & $-3.996 * * *$ & -1.871 & $-3.363 * * *$ \\
\hline & $(2.302)$ & $(0.995)$ & $(1.192)$ & $(0.789)$ \\
\hline \multirow[t]{2}{*}{ yr_6 } & -2.116 & $-3.853 * * *$ & -1.591 & $-3.139 * * *$ \\
\hline & $(2.376)$ & $(1.008)$ & $(1.122)$ & $(0.812)$ \\
\hline \multirow[t]{2}{*}{$\mathrm{yr}=7$} & -2.966 & $-4.073 * * *$ & $-2.033 * *$ & $-3.148 * * *$ \\
\hline & $(2.433)$ & $(1.039)$ & $(1.004)$ & $(0.842)$ \\
\hline \multirow[t]{2}{*}{$\mathrm{yr} \_8$} & -2.430 & $-2.915 * * *$ & $-2.161 * *$ & $-2.792 * * *$ \\
\hline & $(2.186)$ & $(0.953)$ & $(0.986)$ & $(0.685)$ \\
\hline \multirow[t]{2}{*}{ yr_9 } & $-3.942 *$ & $-3.302 * * *$ & $-3.557 * * *$ & $-3.249 * * *$ \\
\hline & $(2.234)$ & $(0.923)$ & $(0.908)$ & $(0.627)$ \\
\hline \multirow[t]{2}{*}{$\mathrm{yr} \_10$} & $-5.011 * *$ & $-3.844 * * *$ & $-4.490 * * *$ & $-3.637 * * *$ \\
\hline & $(2.276)$ & $(0.903)$ & $(0.880)$ & $(0.550)$ \\
\hline \multirow[t]{2}{*}{ yr_11 } & $-5.336 * *$ & $-3.743 * * *$ & $-4.896 * * *$ & $-3.630 * * *$ \\
\hline & $(2.208)$ & $(0.886)$ & $(0.733)$ & $(0.443)$ \\
\hline \multirow[t]{2}{*}{$\mathrm{yr} \_12$} & $-4.738 * *$ & $-3.305 * * *$ & $-4.611 * * *$ & $-3.425 * * *$ \\
\hline & $(2.175)$ & $(0.890)$ & $(0.714)$ & $(0.367)$ \\
\hline \multirow[t]{2}{*}{ yr_13 } & -3.325 & $-2.367 * * *$ & $-3.415 * * *$ & $-2.612 * * *$ \\
\hline & $(2.186)$ & $(0.893)$ & $(0.628)$ & $(0.348)$ \\
\hline \multirow[t]{2}{*}{ yr_14 } & -2.117 & $-1.859 * *$ & $-2.282 * * *$ & $-2.094 * * *$ \\
\hline & (2.118) & $(0.912)$ & $(0.573)$ & $(0.327)$ \\
\hline \multirow[t]{2}{*}{ yr_15 } & -1.079 & -1.199 & $-1.319 * * *$ & $-1.415 * * *$ \\
\hline & (2.204) & $(0.984)$ & $(0.415)$ & $(0.280)$ \\
\hline \multirow[t]{2}{*}{ yr_16 } & -0.819 & -0.832 & $-0.846 * * *$ & $-0.846 * * *$ \\
\hline & $(2.119)$ & $(0.965)$ & $(0.293)$ & $(0.155)$ \\
\hline \multirow[t]{2}{*}{ cons } & $28.057 * * *$ & $45.445 * * *$ & $24.516^{* * *}$ & $47.005 * * *$ \\
\hline & $(3.213)$ & $(1.410)$ & $(4.188)$ & $(2.043)$ \\
\hline Obs. & 459 & 459 & 459 & 459 \\
\hline \multicolumn{5}{|c|}{ Standardne pogreške su u zagradama } \\
\hline \multicolumn{5}{|c|}{$* * * p<0.01, * * p<0.05, * p<0.1$} \\
\hline
\end{tabular}


U trećem i četvrtom modelu korišten je panel s random efektima budući da je i za treći i za četvrti model $\mathrm{p}$ - vrijednost Hausmanovog testa bila veća od 5 $\%$. Nadalje, u oba modela je isključena mogućnost postojanja serijske autokorelacije budući da je $\mathrm{p}$ - vrijednost Pesaran testa u oba modela bila veća od $5 \%$ te je analiza provedena $\mathrm{s}$ robusnim standardnim pogreškama. U trećem modelu, sa stopom zaposlenosti mladih kao zavisnom varijablom, varijabla od interesa institucionalni okvir (comp1) je pozitivnog predznaka i statistički signifikantna na razini od $1 \%$. Drugim riječima, poboljšanje institucionalnog okvira za 1 dovodi do povećanja stope zaposlenosti mladih za 2,980\%, uz ostale varijable konstantne. Ostvarene investicije (gfcf) su također statistički signifikantne i pozitivnog predznaka dok inflacija (inf) i dummy varijabla (eu) nisu statistički signifikantne na razini od $1 \%, 5 \%$ ili $10 \%$.

$\mathrm{U}$ četvrtom modelu, s ukupnom stopom zaposlenosti kao zavisnom varijablom, rezultati su približno slični kao i u trećem modelu. Ponovno je varijabla od interesa institucionalni indeks pozitivna i statistički signifikantna na razini od $1 \%$. Drugim riječima, povećanje institucionalnog indeksa za 1 dovodi do porasta ukupne stope zaposlenosti za 1,460 \%, uz ostale varijable konstantne.

U sva četiri modela varijabla od interesa institucionalni indeks je pozitivna i statistički signifikantna na razini od $1 \%$. Provedena analiza samo potvrđuje činjenicu da različiti institucionalni okviri uvelike utječu na stopu zaposlenosti i stopu zaposlenosti mladih te jednim dijelim mogu objasniti zaostajanje pojedinih zemalja članica Europske unije za vodećim zemljama članicama. Nositelji vlasti trebali bi usmjeriti napore u poboljšanju zakonodavnog okvira onih institucija koje odlučujuće utječu na smanjivanje stupnja korupcije u gospodarstvu, povećanje stupnja zaštite vladavine prava te poboljšanje stupnja regulacije, koja će poboljšati kvalitetu provođenja javnih politika i razvoj privatnog sektora.

\section{ZAKLJUČAK}

Još od svoje samostalnosti devedesetih godina, Republika Hrvatska bilježi zaostajanje prema većini makroekonomskih pokazatelja u odnosu na vodeće zemlje članice Europske unije. To zaostajanje donekle je ublažene u razdoblju od 2000. do2008. godine da bi se ponovno intenziviralo u doba nakon globalne ekonomske krize. Šest dugih godina pada realnog BDP-a Republike Hrvatske samo je dodatno ogolilo većinu strukturnih problema s kojim se Republika Hrvatska suočava. Ti problemi nisu zaobišli ni tržište rada Republike Hrvatske. U usporedbi s ostalim zemljama članicama Europske unije, Hrvatska ima jednu od najnižih stopa zaposlenosti i stopa zaposlenosti mladih. Konkretno, u 2019. godini stopa zaposlenosti Republike Hrvatske iznosila je 62 \% (Poljske $68,2 \%$, Slovenije $72 \%$ ), dok je stopa zaposlenosti mladih iznosila 27,7 \% (Poljske 31,7 \%, Slovenije 33,3 \%). Činjenica koja dodatno zabrinjava je stopa participacije koja je u 2019. godini bila druga najgora u Europskoj uniji, gdje je lošiju stopu participacije imala jedino Italija. 
Razloge gospodarskog zaostajanja Republike Hrvatske nije moguće jednoznačno odrediti, budući da su oni rezultat niza različitih faktora. Na temelju provedene empirijske analize na 27 zemalja članica Europske unije u razdoblju od 2002. do 2018. godine može se zaključiti da je jedan od faktora zaostajanja svakako institucionalni okvir unutar kojeg se odvijaju ekonomske djelatnosti u Republici Hrvatskoj. Konkretno, empirijska analiza pokazala je da poboljšanje institucionalnog indeksa za 1 u 27 zemalja članica Europske unije dovodi do povećanja stope zaposlenosti za 1,460\%, odnosno povećanja stope zaposlenosti mladih za 2,980 \%, uz ostale varijable konstantne.

U skladu s dobivenim rezultatima i stanjem na tržištu rada u Republici Hrvatskoj, s pravom se može tvrditi da su „pravila igre“, odnosno institucionalni okviri jedni od glavnih čimbenika ekonomskog i društvenog zaostajanja Republike Hrvatske.

Rad ima nekoliko ograničenja koja je potrebno uzeti u obzir. Prvo, samo istraživanje institucionalne ekonomije uvijek se provodi s određenom dozom subjektivizma kojeg je potrebno uzeti u obzir prilikom samoga interpretiranja indeksa dobivenog preko PCA analize. Drugo, analiza je provedena na 27 zemalja Europske unije koje se u globalnom kontekstu mogu promatrati svaka za sebe. Institucionalne okvire pojedinih zemalja potrebno je razmatrati unutar socijalnih, ekonomskih i povijesnih okolnosti koji su različiti za svaku zemlju. Iz tog razloga, poboljšanja u pojedinim institucionalnim okvirima mogu rezultirati različitim rezultatima za svaku zemlju. U budućem istraživanju cilj je analizu premjestiti iz domene indeksa u domenu pojedinačnih varijabli kako bi se stupanj subjektivizma smanjio na najmanju moguću mjeru te će se nastojati definirati koje su to institucije koje odlučujuće utječu na veći gospodarski razvoj u pojedinim zemalja.

\section{LITERATURA}

Aralica, Z., Bačić, K., Svilokos, T., (2018). Institutions, and firms' performances in transition countries: the case of the selected CESEE countries. South East European Journal of Economics and Business, 13(1), str. 68-80. https://doi.org/10.2478/jeb-2018-0005

Beck, T., Laeven, L. (2006). Institution Building and Growth in Transition Economies. Journal of Economic Growth, Springer, vol. 11(2), str. 157-186., June. https://doi.org/10.1007/s10887-006-9000-0

Bečić, M., \& Vojinić, P. (2019). Non-Standard Employment and Wages across Sectors in Croatia. 29th EBES CONFERENCE - LISBON, str. 410-423.

Bejaković, P., \& Gotovac, V. (2011). Aktivnosti na gospodarskom oporavku u Republici Hrvatskoj s naglaskom na tržište rada. Revizija za socijalnu politiku, 18(3), str. 331 - 355. https://doi.org/10.3935/rsp.v18i3.1021

Botić, V., \& Tomić, I. (2016). Self - employment of the young and the old: exploring effects of the crisis in Croatia. EIZ - Working papers, str. 5-29.

Brandolini, A., i Viviano, E. (2018). Measuring employment and unemployment. IZA World of Labor, str. 1-12. https://doi.org/10.15185/izawol.445 
Di Tommaso, M. L., Raiser, M., Weeks, M. (2007). Home Grown or Imported? Initial Conditions, External Anchors and the Determinants of Institutional Reform in the Transition Economies. The Economic Journal, Vol. 117, No. 520, str. 858-881., April. https://doi.org/10.1111/j.1468-0297.2007.02053.x

Efendić, A. S., \& Pugh, T. G. (2010). Institutions and economic performance: System GMM modelling of institutional. Acta Oeconomica, str. 1-23.

Falcetti, E., Lysenko, T., Sanfey, P. (2006). Reforms and growth in transition: Re-examining the evidence. Journal of Comparative Economics, Vol. 34, Issue 3, str. 421445. https://doi.org/10.1016/j.jce.2006.06.008

International Labour Organization. (2017). Quick guide on sources and uses of labour statistics. International Labour Organization.

Lane, Jan - Erik, Rohner, D., (2004). Institution Building and Spillovers. Swiss Political Science Review, str. 77 - 90. https://doi.org/10.1002/j.1662-6370.2004.tb00349.x

North, D. C. (1990) Institutions, institutional change, and economic performance. New York: Cambridge University Press. https://doi.org/10.1017/CBO9780511808678

Pääkkönen, J., (2009). Economic freedom as a driver for growth in transition. BOFIT Discussion Papers 1/2009, Bank of Finland, Institute for Economies in Transition, str. 3 - 20. https://doi.org/10.2139/ssrn.1341625

Redek, T., Susjan, A. (2005). The Impact of Institutions on Economic Growth: The Case of Transition Economies. Journal of Economic Issues, 39(4), str. 995-1027. https://doi.org/10.1080/00213624.2005.11506864

Sachs, J. D., (1996). The Transition at Mid Decade. American Economic Review, American Economic Association, Vol. 86, No. 2, str. 128-133.

Tabachnick, B. G., Fidell, L. S., (2014). Using Multivariate Statistics, 6th edition. Pearson Education Limited, USA

Tica, J. (2015). Bilješke za naprednu makroekonomiju. Zagreb.

Tomić, I., Rubil, I., Nestić, D., \& Stubbs, P. (2019). The employment and social situation in Croatia. str. 5 - 39., October

Vujčić, B., (1998). Structural Changes in Employment: Where we are, How we got There and Where are we going to? CNB - Working paper, str. 1-15.

Internet izvori:

https://ec.europa.eu/eurostat (15.12.2020.)

https://www.worldbank.org/ (17.12.2020.) 


\section{DODATAK}

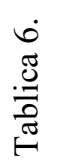

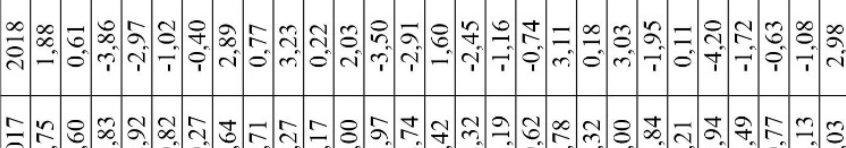
כૈ.

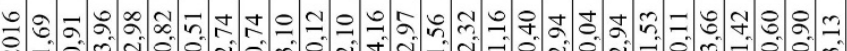

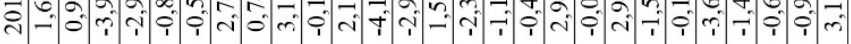
$\because \infty \infty$ กิ의 ते

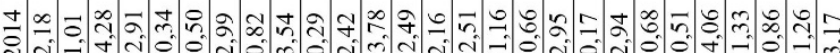

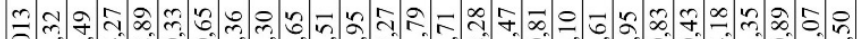

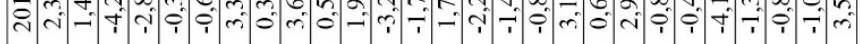

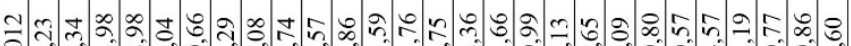

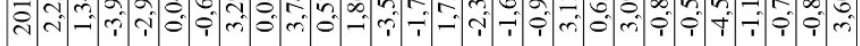

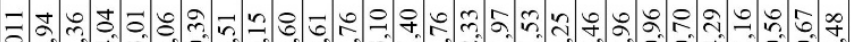

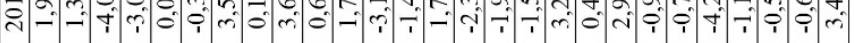

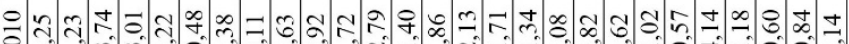
वे तै जी

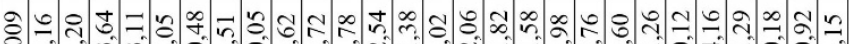
ते जी

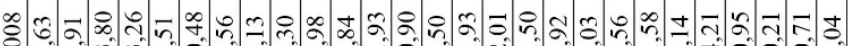

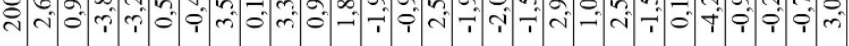

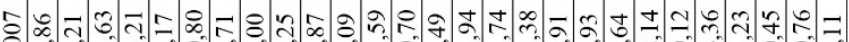

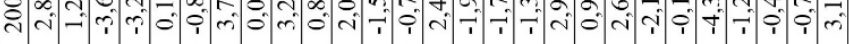

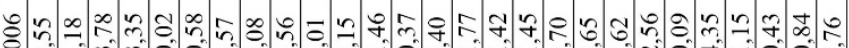

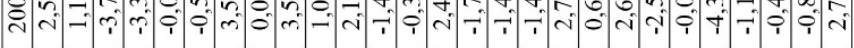

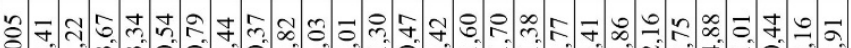

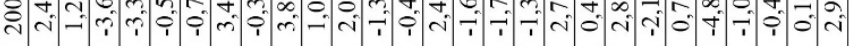
両

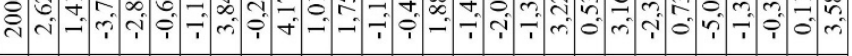

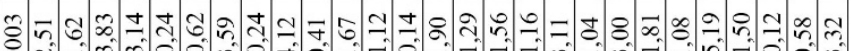
ते

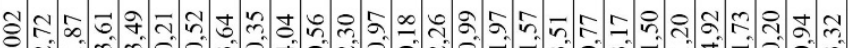

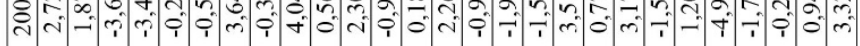

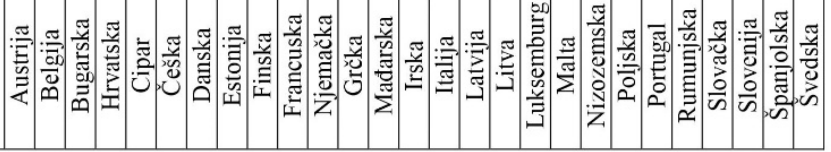




\section{Definiranje varijabli i izvora podataka}

Tablica 7.

\begin{tabular}{|c|c|c|}
\hline st & $\begin{array}{l}\text { Stopa zaposlenosti } 15+\text { prema definiciji Međunarodne } \\
\text { organizacije rada mjeri udio zaposlenih osoba u radno sposobnom } \\
\text { stanovništvu. }\end{array}$ & $\begin{array}{l}\text { WDI - Svjetska } \\
\text { banka }\end{array}$ \\
\hline stm & $\begin{array}{l}\text { Stopa zaposlenosti mladih } 15-24 \text { godine prema definiciji } \\
\text { Međunarodne organizacije rada mjeri udio mladih zaposlenih } \\
\text { osoba u radno sposobnom stanovništvu. }\end{array}$ & $\begin{array}{l}\text { WDI- Svjetska } \\
\text { banka }\end{array}$ \\
\hline $\inf$ & Inflacija mjerena kao indeks potrošačkih cijena (CPI) u \% & $\begin{array}{l}\text { WDI- Svjetska } \\
\text { banka }\end{array}$ \\
\hline gfcf & Ostvarene investicije kao postotak GDP - a & $\begin{array}{c}\text { WGI - Svjetska } \\
\text { Banka }\end{array}$ \\
\hline eu & $\begin{array}{l}\text { Dummy varijabla koja poprima vrijednost } 1 \text { ako je zemlja } i \text { u } \\
\text { periodu } t \text { bila članica Europske unije, u suprotnom } 0 \text {. }\end{array}$ & Europska unija \\
\hline comp1 & $\begin{array}{l}\text { Varijabla koja mjeri učinak institucija i dobivena je pomoću PCA } \\
\text { (Principal component analysis) sumiranjem } 6 \text { varijabli: kontrole } \\
\text { korupcije, efikasnost vlade, političke stabilnosti i odsustva } \\
\text { nasilja/terorizma, kvalitete regulacije, vladavine prava i prava } \\
\text { glasa i slobode govora }\end{array}$ & $\begin{array}{l}\text { WGI - Svjetska } \\
\text { Banka }\end{array}$ \\
\hline $\mathrm{cc}$ & $\begin{array}{l}\text { Kontrola korupcije obuhvaća percepciju korupcije javne vlasti te } \\
\text { se vrijednost varijable kreće u rasponu od }-2,5 \text { do } 2,5 \text {. Veća } \\
\text { vrijednost varijable predstavlja manju percepciju korupcije. }\end{array}$ & $\begin{array}{l}\text { WGI - Svjetska } \\
\text { Banka }\end{array}$ \\
\hline ge & $\begin{array}{l}\text { Efikasnost vlade obuhvaća percepciju vladu u smislu kvalitete } \\
\text { javnih usluga, ekonomskih politika i njihove implementacije kao i } \\
\text { samu kredibilnost vlade. Vrijednost varijable kreće se u rasponu } \\
\text { od }-2,5 \text { do } 2,5 \text { te veća vrijednost predstavlja efikasnu vladu. }\end{array}$ & $\begin{array}{l}\text { WGI - Svjetska } \\
\text { Banka }\end{array}$ \\
\hline ps & $\begin{array}{l}\text { Politička stabilnost } \mathrm{i} \text { odsustvo terorizma/nasilja odnosi se na } \\
\text { percepciju navedenih kategorija. Vrijednost varijable kreće se u } \\
\text { rasponu od }-2,5 \text { do } 2,5 \text { te veća vrijednost varijable predstavlja } \\
\text { veći stupanj političke stabilnosti te odsustva terorizma i nasilja. }\end{array}$ & $\begin{array}{l}\text { WGI - Svjetska } \\
\text { Banka }\end{array}$ \\
\hline rq & $\begin{array}{l}\text { Kvaliteta regulacije odnosi se na percepciju vlade u smislu } \\
\text { provođenja kvalitetnih javnih politika te poticanja razvoja } \\
\text { privatnog sektora. Vrijednost varijable kreće se u rasponu od }-2.5 \\
\text { do } 2,5 \text { te veće vrijednost predstavlja veći stupanj kvalitete } \\
\text { regulacije. }\end{array}$ & $\begin{array}{l}\text { WGI - Svjetska } \\
\text { Banka }\end{array}$ \\
\hline rol & $\begin{array}{l}\text { Vladavina prava odnosi se na percepciju koju agenti imaju prema } \\
\text { socijalnim pravima, poštivanju ugovora, sudovima i sl. Vrijednost } \\
\text { varijable kreće se u rasponu od }-2,5 \text { do } 2,5 \text { te veća vrijednost } \\
\text { predstavlja veći stupanj vladavine prava. }\end{array}$ & $\begin{array}{l}\text { WGI - Svjetska } \\
\text { Banka }\end{array}$ \\
\hline va & $\begin{array}{l}\text { Pravo glasa i sloboda govora obuhvaća percepciju prema kojoj } \\
\text { građani imaju pravo sudjelovanja na izborima, pravo govora, } \\
\text { slobodu medija i sl. Vrijednost varijable kreće se u rasponu od - } \\
2,5 \text { do } 2,5 \text { te veća vrijednost varijable predstavlja veći stupanj } \\
\text { prava glas i slobode govora. }\end{array}$ & $\begin{array}{l}\text { WGI - Svjetska } \\
\text { Banka }\end{array}$ \\
\hline yri & Dummy varijabla za godina u panelu & \\
\hline
\end{tabular}

Izvor: sistematizacija autora 


\title{
Ante Zdilar, mag. oec.
}

Teaching and Research Assistant

University of Dubrovnik

Department of Economics and Business

E-mail: azdilar@unidu.hr

Orcid: https://orcid.org/0000-0001-9411-3409

\section{LABOUR MARKET TRENDS IN CROATIA AND EUROPEAN UNION: THE IMPORTANCE OF FORMAL INSTITUTIONS}

\begin{abstract}
The lag of the Republic of Croatia behind the leading member states of the European Union has always been the dominant topic of empirical research in the domestic economy. The situation in the labour market in 2019, where the Republic of Croatia records one of the lowest employment rate and the participation rates, further confirms the fact of the relative lagging behind the leading EU member states. The aim of this research is to explore the relationship between the institutional framework as one of the possible lagging factors and the overall employment rate and youth employment rate in 27 EU Member States in the period 2002-2018. The results of the research indicate that this relationship is positive and statistically significant for both employment rate and youth employment rate.
\end{abstract}

Keywords: employment rate, youth employment rate, institutions, Republic of Croatia, panel, European Union

JEL classification: J20, J21 